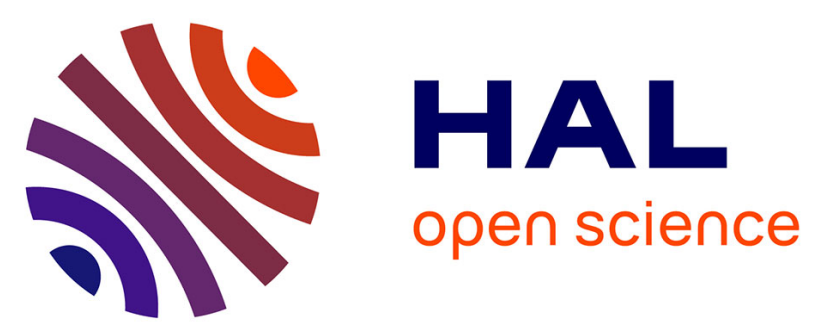

\title{
WaVIL : a Differential Absorption LIDAR for Water Vapor and Isotope HDO Observation in the Lower Troposphere -Instrument Design
}

\author{
Jonas Hamperl, Clément Capitaine, Rosa Santagata, Jean-Baptiste
}

Dherbecourt, Jean-Michel Melkonian, Antoine Godard, Myriam Raybaut, Laurence Régalia, Bruno Grouiez, Frédéric Blouzon, et al.

\section{To cite this version:}

Jonas Hamperl, Clément Capitaine, Rosa Santagata, Jean-Baptiste Dherbecourt, Jean-Michel Melkonian, et al.. WaVIL : a Differential Absorption LIDAR for Water Vapor and Isotope HDO Observation in the Lower Troposphere -Instrument Design. Laser Applications to Chemical, Security and Environmental Analysis 2020, Jun 2020, Washington, United States. pp.LM4A.4, 10.1364/LACSEA.2020.LM4A.4 . hal-03152591

\author{
HAL Id: hal-03152591 \\ https://hal.science/hal-03152591
}

Submitted on 25 Feb 2021

HAL is a multi-disciplinary open access archive for the deposit and dissemination of scientific research documents, whether they are published or not. The documents may come from teaching and research institutions in France or abroad, or from public or private research centers.
L'archive ouverte pluridisciplinaire HAL, est destinée au dépôt et à la diffusion de documents scientifiques de niveau recherche, publiés ou non, émanant des établissements d'enseignement et de recherche français ou étrangers, des laboratoires publics ou privés. 


\title{
WaVIL : a Differential Absorption LIDAR for Water Vapor and Isotope HDO Observation in the Lower Troposphere - Instrument Design
}

\author{
J. Hamperl ${ }^{1}$, C. Capitaine ${ }^{2}$, R. Santagata ${ }^{1}$, J.-B. Dherbecourt ${ }^{1, *}$, J.-M. Melkonian ${ }^{1}$, A. Godard ${ }^{1}$, M. Raybaut ${ }^{1}$, \\ L. Régalia ${ }^{2}$, B. Grouiez ${ }^{2}$, F. Blouzon ${ }^{3}$, N. Geyskens', C. Evesque ${ }^{3}$, P. Chazette ${ }^{5}$, J. Totems ${ }^{5}$, C. Flamant \\ DPHY, ONERA, Université Paris Saclay, F-91123 Palaiseau, France \\ ${ }^{2}$ Groupe de Spectrométrie moléculaire et atmosphérique (GSMA) UMR 7331, URCA, France \\ ${ }^{3}$ Division Technique INSU (DT INSU), UPS 855, Meudon, France \\ ${ }^{4}$ Institut Pierre-Simon Laplace (IPSL), FR636, Guyancourt, France \\ ${ }^{5}$ Laboratoire des Sciences du Climat et de l'Environnement (LSCE), UMR 1572, CEA-CNRS-UVSQ, Gif-sur-Yvette, France \\ ${ }^{6}$ Laboratoire Atmosphères Milieux et Observations Spatiales (LATMOS), UMR 8190, CNRS-SU-UVSQ, Paris, France \\ Author e-mail address: jean-baptiste.dherbecourt@onera.fr
}

\begin{abstract}
We present the design of a differential absorption LIDAR targeting $\mathrm{HDO} / \mathrm{H}_{2}{ }^{16} \mathrm{O}$ isotopic ratio measurement with high vertical resolution. This approach is enabled by infrared water vapor spectroscopy and recent high power multi-species parametric emitter developments.
\end{abstract}

\section{Introduction}

Stable Hydrogen or Oxygen isotopes in water are useful natural tracers of the hydrological origins of air masses and of dynamic atmospheric processes [1]. To improve the water cycle representation, bringing vertical range resolved observations of the relative abundance in $\mathrm{HDO}\left(\delta D\right.$ which depends on the ratio of $\mathrm{HDO}$ and $\left.\mathrm{H}_{2}{ }^{16} \mathrm{O}\right)$ in the low troposphere $(0-3 \mathrm{~km})$ is expected to significantly complement the current knowledge and increase the models accuracy in the predicted magnitude of climate change [2]. To produce this type of data, the range resolved DIAL method is of prime interest, and together with the recent development efforts on multiple-species instrumentation [3-5], the technique is opening the path to co-located measurement in time and space of $\mathrm{H}_{2} \mathrm{O}$ and $\mathrm{HDO}$ with high vertical resolution. In this paper we: $i$ ) define and characterize the proper spectral absorption lines enabling simultaneous measurement of $\mathrm{H}_{2}{ }^{16} \mathrm{O}$ and $\mathrm{HDO}$ with a single instrument, $\mathrm{ii}$ ) propose the design and the projected performances for a new LIDAR instrument capable of addressing both species.

\section{Line selection for $\delta D$ retrieval and DIAL set-up for low troposphere probing}
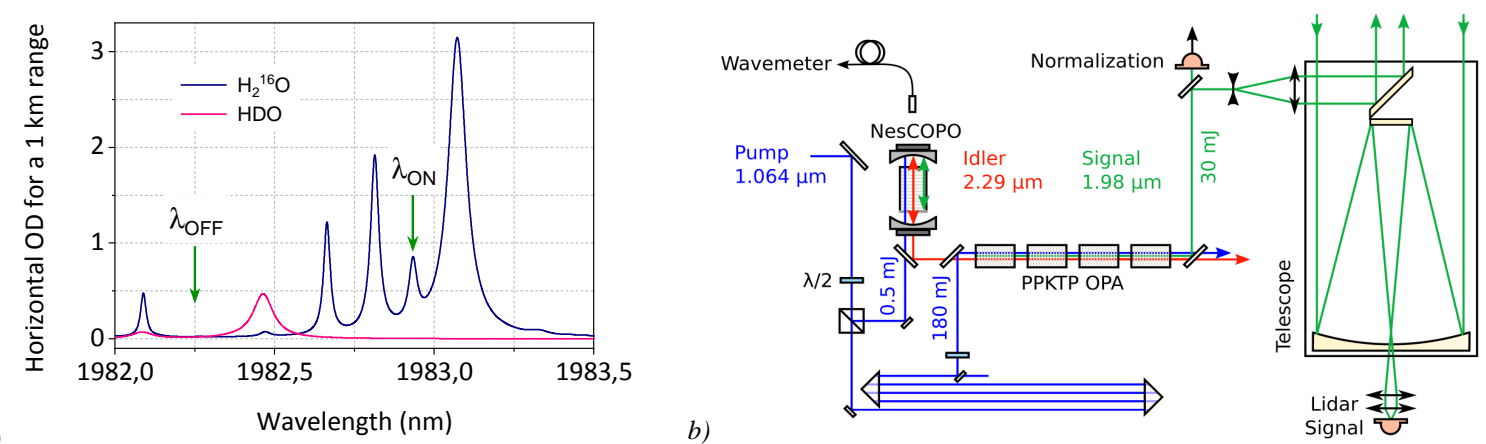

Fig. 1. a) Spectral region of interest for simultaneous probing of $\mathrm{H}_{2}{ }^{16} \mathrm{O}$ and $\mathrm{HDO}$ with a long range DIAL. The optical depths are calculated for $1 \mathrm{~km}$ range at ground level. The marked $\mathrm{ON}$ and OFF wavelength are used for sensitivity simulation on $\mathrm{H}_{2}{ }^{16} \mathrm{O}, b$ ) Schematic of the DIAL emitter (high energy OPO/OPA parametric source) and receiver (high aperture Cassegrain type telescope with InGaAs PIN photodiode).

The key to independent measurement of $\mathrm{HDO}$ and $\mathrm{H}_{2} \mathrm{O}$ concentration is to properly select a spectral region where the two molecules display well separated lines, while preserving a similar and sufficient differential absorption in order to make the LIDAR works in equivalent dynamic and relative precision ranges for both isotopes. This makes the line selection extremely limited since $\delta D$ values range from a few $10 \%$ o to a few $100 \%$. The spectral window between $1982-1984 \mathrm{~nm}$ is well suited for all these purposes as illustrated in Fig.1 (a). To support the end-to-end simulation of the LIDAR performances and gas concentration retrieval, the spectroscopic line parameters have been experimentally measured with high accuracy in the GSMA laboratory with an IFS $125 \mathrm{HR}$. 
The DIAL system is based on a generic OPO/OPA architecture for the emitter depicted in Fig. 2(b), which has been developed at ONERA in the recent years. The approach relies on the combination of a doubly resonant Nested Cavity Optical Parametric Oscillator (NesCOPO) and Optical Parametric Amplifier (OPA), which intrinsically delivers single frequency high energy pulses with adequate tunability for multiple-species probing as demonstrated in the $2 \mu \mathrm{m}$ range [3]. The latest design has been simplified for the OPA line thanks to the recent advent of high aperture (up to $\left.5 \times 5 \mathrm{~mm}^{2}\right)$ PPKTP nonlinear crystals [6], which combine high nonlinearity $\left(\mathrm{d}_{\text {eff }}>9 \mathrm{pm} / \mathrm{V}\right)$ and high damage threshold $\left(>10 \mathrm{~J} / \mathrm{cm}^{2}\right)$. With $180 \mathrm{~mJ}$ energy pulses at $1 \mu \mathrm{m}$ pumping a combination of four PPKTP (total interaction length of $40 \mathrm{~mm}$ ), an extracted signal energy of $30 \mathrm{~mJ}$ at $1982 \mathrm{~nm}$ is expected at the emitter output. The receiver part is based on a $40 \mathrm{~cm}$ diameter primary mirror, and the detection part is a combination of PIN InGaAs photodiode and low noise amplifier, with a $0.6 \mathrm{pW} / \sqrt{\mathrm{Hz}} \mathrm{NEP}$ over a $1.8 \mathrm{MHz}$ bandwidth at ambient temperature.

\section{Sensitivity analysis}

\begin{tabular}{|c|c|c|c|}
\hline \multicolumn{2}{|c|}{ Transmitter } & \multicolumn{2}{|c|}{ Receiver } \\
\hline Energy & $30 \mathrm{~mJ}$ & Aperture & $40 \mathrm{~cm}$ \\
\hline Duration & $10 \mathrm{~ns}$ & FOV & $630 \mu \mathrm{rad}$ \\
\hline On-Off rate & $75 \mathrm{~Hz}$ & $\begin{array}{l}\text { Detector } \\
\text { Type }\end{array}$ & InGaAs PIN \\
\hline Linewidth & $60 \mathrm{MHz}$ & $\begin{array}{l}\text { Detector } \\
\text { diameter }\end{array}$ & $300 \mu \mathrm{m}$ \\
\hline Divergence & $360 \mu \mathrm{rad}$ & NEP & $0.6 \mathrm{pW} / \sqrt{\mathrm{Hz}}$ \\
\hline $\begin{array}{l}\lambda_{\mathrm{ON}} \\
\lambda_{\mathrm{OFF}}\end{array}$ & $\begin{array}{l}1982.93 \mathrm{~nm} \\
1982.25 \mathrm{~nm}\end{array}$ & Bandwidth & $1 \mathrm{MHz}$ \\
\hline
\end{tabular}

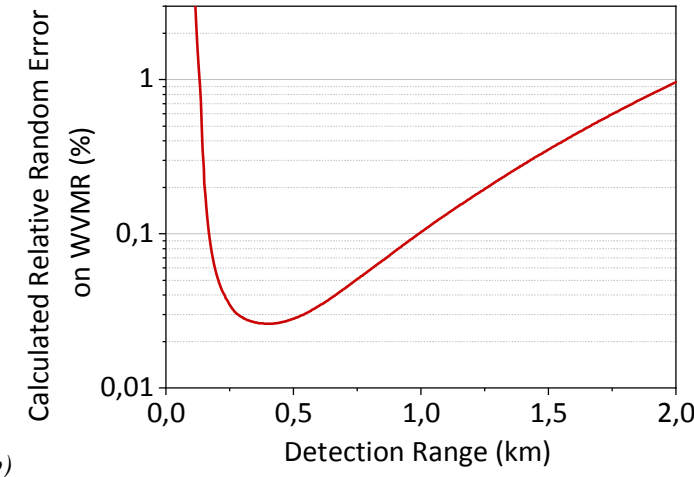

Fig. 2. a) Example of parameters set for the simulation. $b$ ) Expected relative random error on WaterVapor Mixing ratio (WVMR) in the vertical direction over a $2 \mathrm{~km}$ range. The dominant noise source is the detector electronic amplifier. The bandwidth is limited by a $1 \mathrm{MHz}$ low-pass filter.

The main LIDAR parameters are summarized in Fig. 3(a). The simulation is performed by considering a vertical probing and a simplified atmospheric configuration in order to give a first glance estimate of the expectable sensitivity. Pressure and temperature variations follow the US standard atmospheric model. The vertical distribution of aerosols is supposed to bring a uniform backscattering coefficient of $\beta_{\pi}=4.10^{-7} \mathrm{sr}^{-1} \cdot \mathrm{m}^{-1}$, and relative humidity $(\mathrm{RH})$ is also taken uniformly equal to $50 \%$ over the first $2 \mathrm{~km}$, which corresponds to a Water Vapor Mixing Ratio (WVMR) varying from $6 \mathrm{~g} / \mathrm{kg}$ (at $0 \mathrm{~km}$ ) to $3 \mathrm{~g} / \mathrm{kg}$ (at $2 \mathrm{~km}$ ). Finally, the signal averaging is performed for $10 \mathrm{~min}$ accumulation time (90000 laser shots in total), and a $1 \mathrm{MHz}$ bandwidth (150 $\mathrm{m}$ range resolution). With these parameters, the expected relative random error on WVMR is expected to be lower than $1 \%$ in the first $2 \mathrm{~km}$ of the atmosphere. Given the absorption of HDO at $1982 \mathrm{~nm}$ similar relative random error levels are to be expected on HDO mixing ratio, and thus finally on the retrieved value of $\delta D$.

Acknowledgment: The WaVIL project is supported by ANR grant $\mathrm{n}^{\circ}$ ANR-16-CE01-0009.

\section{References}

[1] J. Galewsky, H. C. Steen-Larsen, R. D. Field, J. Worden, C. Risi, and M. Schneider, "Stable isotopes in atmospheric water vapor and applications to the hydrologic cycle," Rev. Geophys. 54, 809-865 (2016).

[2] H. C. Steen-Larsen, C. Risi, M. Werner, K. Yoshimura, and V. Masson-Delmotte, "Evaluating the skills of isotope-enabled general circulation models against in situ atmospheric water vapor isotope observations," J. Geophys. Res. Atmospheres 122, 246-263 (2017).

[3] E. Cadiou, J.-B. Dherbecourt, M. Raybaut, G. Gorju, J.-M. Melkonian, A. Godard, and J. Pelon, "Multiple-Species DIAL for $\mathrm{H}_{2} \mathrm{O}$, CO${ }_{2}$, and $\mathrm{CH}_{4}$ remote sensing in the $1.98-2.30 \mu \mathrm{m}$ range," in Imaging and Applied Optics 2018 (2018), Paper LTu5C.5 (Optical Society of America)

[4] G. A. Wagner, and D. F. Plusquellic, "Multi-frequency differential absorption LIDAR system for remote sensing of $\mathrm{CO}_{2}$ and $\mathrm{H}_{2} \mathrm{O}$ near $1.6 \mu \mathrm{m}, "$ Opt. Express 26, 19420-19434 (2018).

[5] T. F. Refaat, U. N. Singh, J. Yu, M. Petros, S. Ismail, M. J. Kavaya, and K. J. Davis, "Evaluation of an airborne triple-pulsed $2 \mu$ m IPDA lidar for simultaneous and independent atmospheric water vapor and carbon dioxide measurements," Appl. Opt. 54, 1387-1398 (2015).

[6] A. Zukauskas, N. Thilmann, V. Pasiskevicius, F. Laurell, and C. Canalias, "5 mm thick periodically poled Rb-doped KTP for high energy optical parametric frequency conversion," Opt. Mater. Express 1, 201-206 (2011). 